\title{
Laparoscopic-assisted total gastrectomy with D2 lymph node dissection: a case of 12-year-old child with advanced gastric cancer
}

Ru-Hong Tu ${ }^{1}$, Jian-Xian Lin ${ }^{1}$, Ping Li ${ }^{1}$, Jian-Wei Xie ${ }^{1}$, Jia-Bin Wang ${ }^{1}$, Jun Lu ${ }^{1}$, Qi-Yue Chen ${ }^{1}$, Long-long $\mathrm{Cao}^{1}$, Mi Lin ${ }^{1}$, Chao-Hui Zheng ${ }^{1^{*}}$, Chang-Ming Huang ${ }^{1^{*}}$

${ }^{1}$ Department of Gastric Surgery, Fujian Medical University Union Hospital, Fuzhou, China

\section{To Cite}

Tu R-H, Lin J-X, Ping L, Xie J-W,Wang J-B, Lu J, Chen Q-Y, Cao L-L, Lin M, Zheng C-H, Huang C-M, Laparoscopic-assisted total gastrectomy with D2 lymph node dissection: a case of 12-year-old child with advanced gastric cancer. J Gastric Surg 2020; 2(1): 2425

\section{Pubblication history}

Received: February 5, 2020

Revised: February ,2020

Accepted: February 20, 2020

Article in press: February 28, 2020

Published on line: March 15, 2020

\section{*Correspondence to}

Chang-Ming Huang

Department of Gastric Surgery, Fujian

Medical University Union Hospital, No.29

Xinquan Road, Fuzhou 350001, China.

cmlr2002@163.com

Telephone: +86-591-83363366

Fax: +86-591-83320319.

Chao-Hui Zheng

Department of Gastric Surgery, Fujian

Medical University Union Hospital, No.29

Xinquan Road, Fuzhou 350001, China.

wwkzch@163.com

Telephone: +86-591-83363366

Fax: +86-591-83320319.

\author{
ABSTRACT \\ The video shows the operation of laparoscopic-assisted total gastrectomy with D2 \\ lymph node dissection for a 12-year-old child with advanced gastric cancer. \\ Keywords: \\ gastric cancer, laparoscopic gastrectomy, children.
}




\section{Background:}

Primary gastric adenocarcinoma is extremely rare in children, with advanced stage, poorer differentiation, lower radical resection rate and poorer prognosis [1-4]. Surgery is the most efficient treatment for gastric cancer in children. However, there is no report on laparoscopic gastrectomy (LG) for gastric cancer in children. Here, we report a laparoscopy-assisted total gastrectomy (LATG) with D2 lymph node (LN) dissection performed on a 12-year-old child with advanced gastric cancer.

\section{Methods:}

A 12-year-old girl admitted our institution because of hematemesis and melena. Preoperative endoscopy and biopsy showed a signet-ring cell carcinoma in the body of stomach. Both ultrasonography and computerized tomography showed no distant metastasis. She was submitted to a LATG with D2 LN dissection in December 21, 2011.

\section{Results:}

The total operation time was $180 \mathrm{~min}$, and the blood loss was $20 \mathrm{ml}$. We also find two anatomic variants of perigastric vessels: absence of the coronary vein and the common hepatic artery ran behind the portal vein. The postoperative pathological was pT4aN0M0, Stage IIB, and the number of dissection LNs was 56 . The postoperative course was smooth with the child resuming diet by postoperative day (POD) 4. She discharged on POD 9. No adjuvant chemotherapy postoperation, until Dec. 2019, she has disease-free survival for 96 months.

\section{Conclusions:}

LG may be benefit for children gastric cancer with the advantages of minimally invasive. However, because of small abdominal space, smaller vessels, and more fragile tissue, this technique still has some difficulties and should be performed by experienced surgeons.

\section{Acknowledgements}

The authors thank Fujian Medical University Union Hospital for her management of our gastric cancer patient database.

\section{Contributors}

All authors were equally involved in this article.

\section{Funding}

None.

\section{Competing interests}

No benefits in any form have been received or will be received from a commercial party related directly or indirectly to the subject of this article.

\section{Availability of data and materials}

The video associated whit this article can be found, in the on-line version, at:

https://www.journalofgastricsurgery.com/index.php/JGS/article/view/14

\section{Provenance and peer review}

Not commissioned; externally peer reviewed.

\section{Open access}

This is an Open Access article distributed in accordance with the Creative Commons Attribution NonCommercial (CC BY-NC 4.0) license, which permits others to distribute, remix, adapt, build upon this work noncommercially, and license their derivative works on different terms, provided the original work is properly cited and the use is non-commercial. See: http:// creativecommons.org/licenses/by-nc/4.0/

\section{References}

[1] Dokueu AI, OztUrk H, Kilinc N, Onen A, Bukte Y, Soker M. Primary gastric adenoearcinoma in a 2.5-year-old girl. Gastric Cancer 2002; 5(4):237-239.

[2] Subbiah V, Varadhachary G, Herzog CE, Huh W. Gastric adenocarcinoma in children and adolescents. Pediatr Blood Cancer 2011; 57(3):524-527.

[3] Aiehbichler BW, Eherer AJ, Petritsch W, Hinterleitner TA, Krejs GJ Gastric adenocarcinoma mimicking aehalasia in a 15-year-old patient: a case report and review of the literature. J Pediatr Castroenterol Nutr 2001; 32(1):103-106.

[4] da Silva EM, W Achatz MI, Martel-Planche G, et. al. TP53 mutation p. R337H in gastric cancer tissues of a 12-year-old male child:evidence for ehimerism involving a common mutant founder haplotype:case report. BMC Cancer 2011; 11:449.

Ethics approval

Not applicable 